\title{
A novel G protein-coupled receptor for gonadotropin-inhibitory hormone in the Japanese quail (Coturnix japonica): identification, expression and binding activity
}

\author{
H Yin ${ }^{1,2}, K_{\text {Ukena }}{ }^{1,2}$, T Ubuka ${ }^{1,2}$ and K Tsutsui ${ }^{1,2}$ \\ ${ }^{1}$ Laboratory of Brain Science, Faculty of Integrated Arts and Sciences, Hiroshima University, Higashi-Hiroshima 739-8521, Japan \\ ${ }^{2}$ Core Research for Evolutional Science and Technology (CREST), Japan Science and Technology Corporation, Tokyo 150-0002, Japan \\ (Requests for offprints should be addressed to K Tsutsui; Email: tsutsui@hiroshima-u.ac.jp)
}

\begin{abstract}
We recently identified a novel hypothalamic dodecapeptide inhibiting gonadotropin release in the Japanese quail (Coturnix japonica). This novel peptide was therefore named gonadotropin-inhibitory hormone $(\mathrm{GnIH})$. The GnIH precursor encoded one GnIH and two GnIHrelated peptides (GnIH-RP-1 and GnIH-RP-2) that shared the same C-terminal motif, Leu-Pro-Xaa-ArgPhe- $\mathrm{NH}_{2}$ (Xaa=Leu or Gln; LPXRF-amide peptides). Identification of the receptor for $\mathrm{GnIH}$ is crucial to elucidate the mode of action of $\mathrm{GnIH}$. We therefore identified the receptor for $\mathrm{GnIH}$ in the quail diencephalon and characterized its expression and binding activity. We first cloned a cDNA encoding a putative GnIH receptor by a combination of $3^{\prime}$ and $5^{\prime}$ rapid amplification of cDNA ends (RACE) using PCR primers designed from the sequence for the receptor for rat RF-amide-related peptide (RFRP), an orthologous peptide of GnIH. Hydrophobic analysis revealed that the putative $\mathrm{GnIH}$ receptor
\end{abstract}

possessed seven transmembrane domains, indicating a new member of the $G$ protein-coupled receptor superfamily. The crude membrane fraction of COS-7 cells transfected with the putative $\mathrm{GnIH}$ receptor cDNA specifically bound to GnIH and GnIH-RPs in a concentrationdependent manner. Scatchard plot analysis of the binding showed that the identified GnIH receptor possessed a single class of high-affinity binding sites $\left(K_{\mathrm{d}}=0.752 \mathrm{nM}\right.$, $B_{\max }=24.8 \mathrm{fmol} / \mathrm{mg}$ protein). Southern blotting analysis of reverse transcriptase-mediated PCR products revealed the expression of $\mathrm{GnIH}$ receptor mRNA in the pituitary gland and several brain regions including diencephalon in the quail. These results suggest that $\mathrm{GnIH}$ acts directly on the pituitary via $\mathrm{GnIH}$ receptor to inhibit gonadotropin release. GnIH may also act on the hypothalamus to inhibit gonadotropin-releasing hormone release.

Journal of Endocrinology (2005) 184, 257-266

\section{Introduction}

Recently, we identified a novel hypothalamic dodecapeptide, Ser-Ile-Lys-Pro-Ser-Ala-Tyr-Leu-Pro-Leu-ArgPhe- $\mathrm{NH}_{2}$, in the brain of Japanese quail (Coturnix japonica; Tsutsui et al. 2000). This avian neuropeptide was shown to inhibit gonadotropin release from the cultured quail anterior pituitary (Tsutsui et al. 2000). This is the first hypothalamic peptide inhibiting gonadotropin release reported in a vertebrate. We therefore termed it gonadotropin-inhibitory hormone $(\mathrm{GnIH}$; Tsutsui et al. 2000). Because GnIH was shown to be located in neurons of the paraventricular nucleus and their terminals in the median eminence (Tsutsui et al. 2000, Ubuka et al. 2003, Ukena et al. 2003a), GnIH may act directly on the pituitary to inhibit gonadotropin release. In addition, GnIH-containing fibers were observed in extremely close proximity to gonadotropin-releasing hormone $(\mathrm{GnRH})$ neurons in the preoptic area in birds (Bentley et al. 2003,
Ukena et al. 2003a). It is therefore plausible that GnIH may act at the level of the hypothalamus to regulate gonadotropin release as well as at the pituitary. To elucidate the mode of action of $\mathrm{GnIH}$ on gonadotropin release, identification of the receptor for $\mathrm{GnIH}$ is crucial in birds.

We also characterized a cDNA encoding the GnIH precursor in the brain of quail (Satake et al. 2001) and sparrow (Osugi et al. 2004). The GnIH precursor encoded one GnIH and two GnIH-related peptides (GnIH-RP-1 and GnIH-RP-2) that included Leu-Pro-Xaa-Arg-Phe$\mathrm{NH}_{2}$ (Xaa = Leu or Gln) at their C-termini (Satake et al. 2001, Osugi et al. 2004). Based on this structural feature, GnIH and GnIH-RPs are considered to be LPXRFamide peptides as a new member of the RF-amide peptide family (Ukena \& Tsutsui 2004). In addition, the chicken pentapeptide LPLRF-amide, which was previously isolated as the first RF-amide peptide found in vertebrates (Dockray et al. 1983), is considered to be a fragment of 
GnIH (Tsutsui et al. 2000, Satake et al. 2001, Osugi et al. 2004).

After the identification of $\mathrm{GnIH}$ in birds, we further sought to identify novel hypothalamic LPXRF-amide peptides similar to GnIH and GnIH-RPs in other vertebrates. The isolated LPLRF-amide peptide from bullfrog hypothalami possessed growth hormone-releasing activity, and was designated as frog growth hormone-releasing peptide (fGRP) (Koda et al. 2002). This fGRP is structurally identical to Rana RF-amide (R-RFa) purified by Chartrel et al. (2002). The fGRP precursor also encoded one fGRP and three related peptides (fGRP-RP-1, -2, and -3; Sawada et al. 2002a), which were identified as mature LPXRF-amide peptides (Ukena et al. 2003b). fGRP-RP-2 also stimulated the release of growth hormone and prolactin (Ukena et al. 2003b). Furthermore, we characterized a cDNA that encoded three LPXRF-amide peptides (gf LPXRFa-1, -2 and -3 ) from the goldfish brain and identified gf LPXRFa-3 as a mature peptide (Sawada et al. 2002b). Turning to mammals, cDNAs that encode LPXRF-amide peptides have been detected in mammalian brains with a gene database search (Hinuma et al. 2000). Mammalian cDNAs encoded three peptides, which were termed RF-amide-related peptide-1, -2 and -3 (RFRP-1, -2 and -3 ). Subsequently, mammalian RFRP-1 and -3 were identified in the bovine and rat brain (Fukusumi et al. 2001, Ukena et al. 2002, Yoshida et al. 2003), although RFRP-2 was not an LPXRF-amide peptide. In mammals, Hinuma et al. (2000) have found that the deduced human LPXRF-amide peptide, human RFRP-1, increased prolactin release in the rat. Another group has also reported the stimulatory effect of RFRP-1 on prolactin release (Samson et al. 2003). Hinuma et al. (2000) have further reported the receptors for rat and human RFRP, which were G protein-coupled receptors (GPCRs).

With these findings as a background, in this study we sought to identify the receptor for GnIH (avian LPXRFamide peptide) in the quail, based on the structure of the receptor for rat RFRP, an orthologous peptide of GnIH. Here we show a novel avian GPCR for GnIH, which specifically binds to GnIH and GnIH-RPs with high affinities. To understand the mode of action of GnIH on gonadotropin release, we further characterized the expression of $\mathrm{GnIH}$ receptor in the pituitary and different brain regions.

\section{Materials and Methods}

\section{Animals and $R N A$ preparation}

Sexually mature males (3 months of age) of the Japanese quail were purchased from the Tokai Yuki Company (Toyohashi, Japan). They were housed in a temperaturecontrolled room $\left(25 \pm 2{ }^{\circ} \mathrm{C}\right)$ under daily photoperiods of $16 \mathrm{~h}$ light and $8 \mathrm{~h}$ dark (long day; lights on at $0700 \mathrm{~h}$ ), and were given quail food and tap water ad libitum. All birds were isolated in individual cages and the experimental protocol was approved in accordance with the Guide for the Care and Use of Laboratory Animals prepared by the committee of Hiroshima University (Higashi-Hiroshima, Japan).

All birds were killed by decapitation between 1000 and $1200 \mathrm{~h}$. The cerebrum, diencephalon, mesencephalon and cerebellum were carefully removed using fine forceps under a dissecting microscope, snap-frozen immediately in liquid nitrogen and used for RNA isolation. Total RNA from quail diencephalons was extracted with Sepazol-RNA I Super reagent (Nacalai Tesque, Kyoto, Japan) followed by the isolation of $\operatorname{poly}(\mathrm{A})^{+}$RNA with Oligotex-(dT) 30 (Daiichikagaku, Tokyo, Japan) in accordance with the manufacturer's instructions.

\section{$5^{\prime} / 3^{\prime}$ Rapid amplification of cDNA ends (RACE) and degenerate PCR cloning}

Utilizing the isolated poly $(\mathrm{A})^{+}$RNA of quail diencephalons and primers corresponding to amino acid sequences of the first extracellular loop (DNATCKM, amino acids 112-118) and second intracellular loop (IVHPFRE, amino acids 145-151) of rat RFRP receptor (accession number AB040103; Hinuma et al. 2000), nested degenerate PCR was performed to determine the cDNA $3^{\prime}$-end sequence of a putative quail $\mathrm{GnIH}$ receptor with the oligo(dT)anchor primer supplied in the $5^{\prime} / 3^{\prime}$ RACE kit (Roche Diagnostics). Both first- and second-round PCRs consisted of the following conditions: $94^{\circ} \mathrm{C}$, hold for $3 \mathrm{~min}$; five cycles of $94{ }^{\circ} \mathrm{C}$ for $30 \mathrm{~s}, 47^{\circ} \mathrm{C}$ for $30 \mathrm{~s}, 72{ }^{\circ} \mathrm{C}$ for $2 \mathrm{~min} ; 30$ cycles of $94^{\circ} \mathrm{C}$ for $30 \mathrm{~s}, 52^{\circ} \mathrm{C}$ for $30 \mathrm{~s}, 72{ }^{\circ} \mathrm{C}$ for $2 \mathrm{~min}$; hold for $3 \mathrm{~min}$ at $72^{\circ} \mathrm{C}(10 \mathrm{~min}$ in the secondround PCR). The second-round PCR products were subcloned into a TA-cloning vector, pGEM-T, in accordance with the manufacturer's instructions (Promega). The DNA inserts of the positive clones were amplified by PCR with universal M13 primers.

Cloning of the $5^{\prime}$-end of a putative quail $\mathrm{GnIH}$ receptor cDNA was carried out with the Advantage GC-2 PCR kit (Clontech). Template cDNA was synthesized with an oligonucleotide primer, 5'-CACGTAGATGTGGGAAA AGAG-3', complementary to nucleotides 748-768 (Fig. 1A), followed by dA-tailing of the cDNA with dATP and terminal transferase (Roche Diagnostics). The tailed cDNA was amplified with the oligo(dT)-anchor primer (Roche Diagnostics) and gene-specific primer $1\left(5^{\prime}\right.$-CTG GTGACAGTTAGGGTGAT-3', complementary to nucleotides 622-641), followed by further amplification of the first-round PCR products with the anchor primer and gene-specific primer 2 (5'-AGCACCCAGATGATGG CAAT-3', complementary to nucleotides 574-593). Both first-round and second-round PCRs were performed for 35 cycles of $94{ }^{\circ} \mathrm{C}$ for $1 \mathrm{~min}, 55^{\circ} \mathrm{C}$ for $1 \mathrm{~min}$ and $72{ }^{\circ} \mathrm{C}$ for $1 \mathrm{~min}$ (10 min for last cycle). The second-round PCR 

CAC CAG GAG CCA AGC GGG GAC ACC TTC AAT GGC AGC TGG GAT AAT GCC AGT GAG AGC CAA ATC CTG AAG GAA AAC TAC ACC TTC TTG GCA TAC TAC CAG CAC 204 $\begin{array}{llllllllllllllllllllllllllllllllllllll}\mathbf{H} & \mathbf{Q} & \mathbf{E} & \mathbf{P} & \mathbf{S} & \mathbf{G} & \mathbf{D} & \mathbf{T} & \mathbf{F} & \mathbf{N} & \mathbf{G} & \mathbf{S} & \mathbf{W} & \mathbf{D} & \mathbf{N} & \mathbf{A} & \mathbf{S} & \mathbf{E} & \mathbf{S} & \mathbf{Q} & \mathbf{I} & \mathbf{L} & \mathbf{K} & \mathbf{E} & \boldsymbol{N} & \mathbf{Y} & \mathbf{T} & \mathbf{F} & \mathbf{L} & \mathbf{A} & \mathbf{Y} & \mathbf{Y} & \mathbf{Q} & \mathbf{H} & & 39\end{array}$ TCC TCG CCC GTG GCT GTG ATG TTC ATC CTA GCC TAC ACC TTC ATC TTC CTC ATG TGC ATG ATT GGC AAC ATC CTG GTG TGC TTC ATC GTG GTG AAG AAC CGA 306 $\begin{array}{lllllllllllllllllllllllllllllllllllllllll}\mathbf{S} & \mathbf{S} & \mathbf{P} & \mathbf{V} & \mathbf{A} & \mathbf{V} & \mathbf{M} & \mathbf{F} & \mathbf{I} & \mathbf{L} & \mathbf{A} & \mathbf{Y} & \mathbf{T} & \mathbf{F} & \mathbf{M I} & \mathbf{I} & \mathbf{F} & \mathbf{L} & \mathbf{M} & \mathbf{C} & \mathbf{M} & \mathbf{I} & \mathbf{G} & \mathbf{N} & \mathbf{I} & \mathbf{L} & \mathbf{V} & \mathbf{C} & \mathbf{F} & \mathbf{I} & \mathbf{V} & \mathbf{V} & \mathbf{K} & \mathbf{N} & \mathbf{R} & 73\end{array}$ CAG ATG CGG ACG GTC ACC AAC ATG TTC ATC CTC AAC CTT GCC ATC AGC GAC CTG CTG GTG GGC ATC TTC TGC ATG CCT ACA ACT CTG GTG GAC AAC CTC ATC 408 $\begin{array}{llllllllllllllllllllllllllllllllllll}\mathbf{Q} & \mathbf{M} & \mathbf{R} & \mathbf{T} & \mathbf{V} & \mathbf{T} & \mathbf{N} & \mathbf{M} & \mathbf{F} & \mathbf{I} & \mathbf{L} & \mathbf{N} & \mathbf{L} & \mathbf{A} & \mathbf{I} & \mathbf{S}_{\mathrm{TMII}} & \mathbf{D} & \mathbf{L} & \mathbf{L} & \mathbf{V} & \mathbf{G} & \mathbf{I} & \mathbf{F} & \mathbf{C} & \mathbf{M} & \mathbf{P} & \mathbf{T} & \mathbf{T} & \mathbf{L} & \mathbf{V} & \mathbf{D} & \mathbf{N} & \mathbf{L} & \mathbf{I} & 107\end{array}$ ACG GGG TGG CCT TTT GAT AAT GCC ATG TGC AAA ATG AGT GGC TTG GTA CAG GGC ATG TCT GTC TCC GCC TCT GTT TTC ACG CTG GTG GCT ATC GCA GTG GAG 510 $\begin{array}{llllllllllllllllllllllllllllllllllllllll}\mathbf{T} & \mathbf{G} & \mathbf{W} & \mathbf{P} & \mathbf{F} & \mathbf{D} & \mathbf{N} & \mathbf{A} & \mathbf{M} & \mathbf{C} & \mathbf{K} & \mathbf{M} & \mathbf{S} & \mathbf{G} & \mathbf{L} & \mathbf{V} & \mathbf{Q} & \mathbf{G} & \mathbf{M} & \mathbf{S} & \mathbf{V} & \mathbf{S} & \mathbf{A} & \mathbf{T M m} & \mathbf{S} & \mathbf{V} & \mathbf{F} & \mathbf{T} & \mathbf{L} & \mathbf{V} & \mathbf{A} & \mathbf{I} & \mathbf{A} & \mathbf{V} & \mathbf{E} & 141\end{array}$ AGG TTT CGC TGC ATC GTC CAC CCG TTC CGG GAG AAG CTG ACG CTG AGG AAA GCC CTG GTG ACC ATT GCC ATC ATC TGG GTG CTG GCC CTG CTC ATC ATG TGC 612 $\begin{array}{lllllllllllllllllllllllllllllllllllllll}\mathbf{R} & \mathbf{F} & \mathbf{R} & \mathbf{C} & \mathbf{I} & \mathbf{V} & \mathbf{H} & \mathbf{P} & \mathbf{F} & \mathbf{R} & \mathbf{E} & \mathbf{K} & \mathbf{L} & \mathbf{T} & \mathbf{L} & \mathbf{R} & \mathbf{K} & \mathbf{A} & \mathbf{L} & \mathbf{V} & \mathbf{T} & \mathbf{I} & \mathbf{A} & \mathbf{I} & \mathbf{I} & \mathbf{W} & \mathbf{V} \\ \mathbf{T M I V} & \mathbf{L} & \mathbf{A} & \mathbf{L} & \mathbf{L} & \mathbf{I} & \mathbf{M} & \mathbf{C} & 175\end{array}$ CCC TCC GCC ATC ACC CTA ACT GTC ACC AGG GAG GAG CAC CAC TTC ATG CTG GAT ACC TAC AAC AAC TCC TAC CCC CTC TAC TCC TGC TGG GAGGCC TGG CCC 714 $\begin{array}{lllllllllllllllllllllllllllllllllllll}\mathbf{P} & \mathbf{S} & \mathbf{A} & \mathbf{I} & \mathbf{T} & \mathbf{L} & \mathbf{T} & \mathbf{V} & \mathbf{T} & \mathbf{R} & \mathbf{E} & \mathbf{E} & \mathbf{H} & \mathbf{H} & \mathbf{F} & \mathbf{M} & \mathbf{L} & \mathbf{D} & \mathbf{T} & \mathbf{Y} & \mathbf{N} & \mathbf{N} & \mathbf{S} & \mathbf{Y} & \mathbf{P} & \mathbf{L} & \mathbf{Y} & \mathbf{S} & \mathbf{C} & \mathbf{W} & \mathbf{E} & \mathbf{A} & \mathbf{W} & \mathbf{P} & 20 & 9\end{array}$ GAG ACA GAG ATG AGG AAG ATC TAC ACT ACC GTC CTC TTT TCC CAC ATC TAC GTG GCA CCC CTC GCC CTC ATT GTC ATC ATG TAT GCC CGC ATT GCC TTC AAG 816 $\begin{array}{lllllllllllllllllllllllllllllllllllllllll}\mathbf{E} & \mathbf{T} & \mathbf{E} & \mathbf{M} & \mathbf{R} & \mathbf{K} & \mathbf{I} & \mathbf{Y} & \mathbf{T} & \mathbf{T} & \mathbf{V} & \mathbf{L} & \mathbf{F} & \mathbf{S} & \mathbf{H} & \mathbf{I} & \mathbf{Y} & \mathbf{V} & \mathbf{T M v} & \mathbf{A} & \mathbf{P} & \mathbf{L} & \mathbf{A} & \mathbf{L} & \mathbf{I} & \mathbf{V} & \mathbf{I} & \mathbf{M} & \mathbf{Y} & \mathbf{A} & \mathbf{R} & \mathbf{I} & \mathbf{A} & \mathbf{F} & \mathbf{K} & 243\end{array}$ CTC TTC AAG TCA GCA GCG CCC GCC CGC AGC ACC CGG CCT GAG GAG CCCGAG GGG AGG AAG GTGTCC CGT AGG AAG GCG AAG GTC ATC AAC ATG CTC ATCATC 918 $\begin{array}{lllllllllllllllllllllllllllllllllllllll}\mathbf{L} & \mathbf{F} & \mathbf{K} & \mathbf{S} & \mathbf{A} & \mathbf{A} & \mathbf{P} & \mathbf{A} & \mathbf{R} & \mathbf{S} & \mathbf{T} & \mathbf{R} & \mathbf{P} & \mathbf{E} & \mathbf{E} & \mathbf{P} & \mathbf{E} & \mathbf{G} & \mathbf{R} & \mathbf{K} & \mathbf{V} & \mathbf{S} & \mathbf{R} & \mathbf{R} & \mathbf{K} & \mathbf{A} & \mathbf{K} & \mathbf{V} & \mathbf{I} & \mathbf{N} & \mathbf{M} & \mathbf{L} & \mathbf{I} & \mathbf{I} & 277\end{array}$ ATG GCC CTC TTC TTC ACC CTC TCC TGG CTG CCC CTC TGG ACA CTG ATG CTG CTT ACA GAC TAC GGG CAC CTC AGC GAG CAC CAG CTG CAC CTG GTC ACC GGC 1020 $\begin{array}{lllllllllllllllllllllllllllllllllllll}\text { M } & \mathbf{A} & \mathbf{L} & \mathbf{F} & \mathbf{T M V} & \mathbf{T} & \mathbf{L} & \mathbf{S} & \mathbf{W} & \mathbf{L} & \mathbf{P} & \mathbf{L} & \mathbf{W} & \mathbf{T} & \mathbf{L} & \mathbf{M} & \mathbf{L} & \mathbf{L} & \mathbf{T} & \mathbf{D} & \mathbf{Y} & \mathbf{G} & \mathbf{H} & \mathbf{L} & \mathbf{S} & \mathbf{E} & \mathbf{H} & \mathbf{Q} & \mathbf{L} & \mathbf{H} & \mathbf{L} & \mathbf{V} & \mathbf{T} & \mathbf{G} & 311\end{array}$ TAC ATC TTT CCC TTT GCC CAC TGG CTG GCT TTC TTC AAC AGC AGC GCC AAC CCC ATC ATC TAC GGC TAC TTC AAT GAG AAC TTC CGA CGG GGC TTC CAG GAG 1122

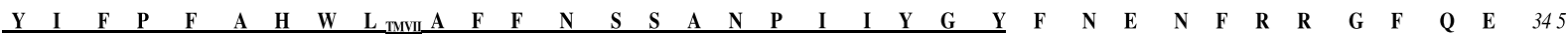
GCC TTCAGA GCC CCTTTC TGGTTG CCACCGTGC CGG CAG CAC CGT GGG CCC TAT GGT GCC CGC AAC CGT GTC TTC ACC CAG CCC CAG GCC AGC GAC TCT CCC 1224 $\begin{array}{lllllllllllllllllllllllllllllllllllllll}\mathbf{A} & \mathbf{F} & \mathbf{R} & \mathbf{A} & \mathbf{P} & \mathbf{F} & \mathbf{W} & \mathbf{L} & \mathbf{P} & \mathbf{P} & \mathbf{C} & \mathbf{R} & \mathbf{Q} & \mathbf{H} & \mathbf{R} & \mathbf{G} & \mathbf{P} & \mathbf{Y} & \mathbf{G} & \mathbf{A} & \mathbf{R} & \mathbf{N} & \mathbf{R} & \mathbf{V} & \mathbf{F} & \mathbf{T} & \mathbf{Q} & \mathbf{P} & \mathbf{Q} & \mathbf{A} & \mathbf{S} & \mathbf{D} & \mathbf{S} & \mathbf{P} & 379\end{array}$ CCGCAC TCA GAA TCG AGGCCA CTG GCA TCC CGA CGG GCC GGC ATC CCT GCG TGG AAT GGC TGA GCA GCT GAG GCC ACC AGC TTG CCT GAT AGA TGT GGG GAC 1326 $\begin{array}{lllllllllllllllllllll}\mathbf{P} & \mathbf{H} & \mathbf{S} & \mathbf{E} & \mathbf{S} & \mathbf{R} & \mathbf{P} & \mathbf{L} & \mathbf{A} & \mathbf{S} & \mathbf{R} & \mathbf{R} & \mathbf{A} & \mathbf{G} & \mathbf{I} & \mathbf{P} & \mathbf{A} & \mathbf{W} & \mathbf{N} & \mathbf{G} & *\end{array}$

CTC GTG CAT GGC ACT GCT GTA GGG TGG ACA CCC CAT ATC ATT GTG GGT TTG GGG TCT TGA TGT GAT GAT CAG TGA GTG TCC AAC CTA AGG GCT TGT TGG GAG 1429 TGGAGGGGAATAGGGGGTTTGTAATGTCACTGCAATAAA GGCACGATGCTG-poly(A)

B

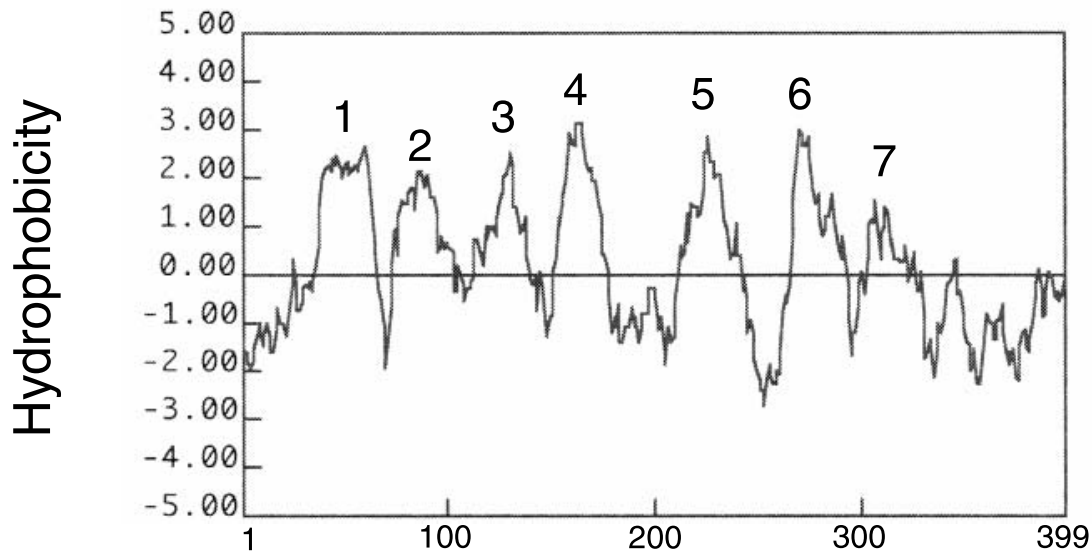

\section{Amino acid number}

Figure 1 Structural analysis of a putative quail GnlH receptor. (A) Nucleotide sequence and deduced amino acid sequence of a putative quail GnIH receptor CDNA. The seven putative TMs are underlined. The N-linked glycosylation sites are indicated in bold italics. The poly $(\mathrm{A})^{+}$adenylation signal AATAAA is shown by a dotted line. (B) Hydrophobicity profile according to the analysis with DNASIS-MAC software (Hitachi, Kanagawa, Japan). 
products were subcloned and the DNA inserts were amplified as described above.

\section{DNA sequencing}

All nucleotide sequences were determined with an ABI Prism Dye terminator cycle-sequencing ready reaction kit (PE-Biosystems, Foster, CA, USA) and a model 373A automated DNA sequencer (PE-Biosystems), then analysed using DNASIS-MAC software (Hitachi Software Engineering, Kanagawa, Japan). Universal M13 primers or gene-specific primers were used to sequence both strands.

\section{Transient transfection}

The full-length open reading frame of the identified putative $\mathrm{GnIH}$ receptor was amplified from quail diencephalon cDNA using the forward primer $5^{\prime}$-GCCG CCACCATGCAGGCGCTGCGGCACCA-3' and the reverse primer 5'-GCTCAGCCATTCCACGCAG GGAT-3', and subcloned into TOPO-pcDNA3.1 (Invitrogen), a mammalian expression vector. 15 positive colonies were selected, subcultured, and all their plasmid DNAs purified by the Wizard plus SV minipreps DNA purification system (Promega) and fully sequenced. The colony that produced the plasmid construct completely identical with the receptor sequence was selected, cultured and purified by the Wizard plus maxipreps DNA purification system (Promega).

COS-7 cells were supplied from Riken Cell Bank (Tsukuba, Japan) and grown in $10 \mathrm{~cm}$ dishes as monolayers in Dulbecco's modified Eagle's medium supplemented with $10 \%$ heat-inactivated fetal calf serum, penicillin $(50 \mathrm{U} / \mathrm{ml})$, streptomycin $(50 \mu \mathrm{g} / \mathrm{ml})$ and Hepes $(10 \mathrm{mM}$, $\mathrm{pH} 7 \cdot 4)$ in $5 \% \mathrm{CO}_{2}$ at $37^{\circ} \mathrm{C}$. Transfection was performed with the TransFast transfection reagent (Promega) according to the manufacturer's instructions. At 2 or 3 days after transfection, the dishes were washed twice with PBS (10 mM phosphate buffer and $140 \mathrm{mM} \mathrm{NaCl}, \mathrm{pH} 7 \cdot 4$ ), and the cells were harvested. The cells were then centrifugated $\left(1300 \mathrm{~g}\right.$ for $10 \mathrm{~min}$ at $\left.4{ }^{\circ} \mathrm{C}\right)$ and stored at $-80{ }^{\circ} \mathrm{C}$.

\section{Radioiodination and binding assay}

The synthetic C-terminal quail GnIH-RP-1 (amino acids 31-37; Satake et al. 2001, Osugi et al. 2004) with an added $\mathrm{N}$-terminal tyrosine residue, YANLPLRF-amide, was radioiodinated with ${ }^{125} \mathrm{I}\left(\mathrm{Na}^{125} \mathrm{I}\right.$; Amersham Biosciences) by the lactoperoxidase method as described previously (Tsutsui \& Ishii 1978, 1980, Tsutsui et al. 1985). Although GnIH contained an endogenous tyrosine residue, the binding activity of $\mathrm{GnIH}$ was reduced by iodination. Therefore, we used the synthetic C-terminal GnIH-RP-1 tagged with the $\mathrm{N}$-terminal tyrosine residue as a ligand of iodination. Labeled YANLPLRF-amide was separated from free ${ }^{125} \mathrm{I}$ on a $\mathrm{C}_{18}$ reversed-phase column (Azumaya \& Tsutsui 1996, Tsutsui et al. 1997, 1998). The specific activity of ${ }^{125}$ I-YANLPLRF-amide was estimated at $200 \mu \mathrm{Ci} / \mathrm{nmol}$. For the receptor preparation, frozen COS-7 cells $\left(1.25 \times 10^{6}\right.$ cells $)$ were rapidly thawed and homogenized with a glass homogenizer with a Teflon Pestle in cold assay buffer (0.04 M Tris- $\mathrm{HCl}$ buffer $(\mathrm{pH}$ $7 \cdot 4$ ) containing $5 \mathrm{mM} \mathrm{MgSO}, 0 \cdot 1 \% \mathrm{BSA}$ and $0 \cdot 1 \mathrm{mM}$ phenylmethylsulfonylfluoride, a protease inhibitor; Tsutsui et al. 1997, 1998). The homogenates were centrifugated at $11000 \mathrm{~g}$ for $20 \mathrm{~min}$ at $4{ }^{\circ} \mathrm{C}$. The resulting pellets were resuspended in cold assay buffer and adjusted as the receptor preparations equivalent to $800 \mu \mathrm{g}$ protein of crude membrane fractions of COS-7 cells/100 $\mu$ l buffer.

Binding experiments were performed as described previously (Azumaya \& Tsutsui 1996, Tsutsui et al. 1997, 1998). In brief, $50 \mu l$ of the non-radioactive peptide in assay buffer or the assay buffer alone, $50 \mu \mathrm{l}$ of the ${ }^{125}$ I-YANLPLRF-amide and $100 \mu \mathrm{l}$ of the receptor preparation $(800 \mu \mathrm{g}$ protein of crude membrane fractions of COS-7 cells) were added to disposable plastic centrifuge tubes with a capacity of $1.5 \mathrm{ml}$. All of the reaction tubes had previously been coated with BSA to reduce the adsorption of peptides to the tube wall. The tubes were placed in a water-bath incubator with continuous shaking at $20^{\circ} \mathrm{C}$ for $1 \mathrm{~h}$. At the end of the incubation period, $1 \mathrm{ml}$ cold assay buffer was added to each tube, and the tubes were centrifugated at $11000 \mathrm{~g}$ for $3 \mathrm{~min}$ at $4{ }^{\circ} \mathrm{C}$. The pellets were then washed twice with cold assay buffer, and the radioactivity of the resulting pellets was counted in an autowell $\gamma$-counter (Aloka, Tokyo, Japan). In order to examine the ligand specificity of the binding to the crude membrane fraction of COS-7 cells transfected with the putative $\mathrm{GnIH}$ receptor cDNA, competition-binding experiments were performed as follows: $1.25 \mathrm{nM}{ }^{125} \mathrm{I}-$ YANLPLRF-amide was incubated with different amounts of GnIH, GnIH-RP-1, GnIH-RP-2, GnIH-OH (C-terminally non-amidated $\mathrm{GnIH}$ ) and other neuropeptides (Met-enkephalin-RF, galanin and neuropeptide Y) which lack the C-terminal LPXRF-amide motif. In the saturation-binding experiment, different amounts of ${ }^{125} \mathrm{I}-$ YANLPLRF-amide $(0.234-3.75 \mathrm{nM})$ were incubated with or without an excess of cold YANLPLRF-amide $(0 \cdot 253-4 \cdot 05 \mu \mathrm{M})$. Scatchard plots were constructed from the data obtained from the saturation-binding experiment. The dissociation constant $\left(K_{\mathrm{d}}\right)$ and the maximal binding sites $\left(B_{\max }\right)$ were then determined with Scatchard plots. Linearity of the Scatchard plots and 95\% confidence intervals for the $K_{\mathrm{d}}$ and $B_{\max }$ were computed according to the method of Bliss (1967).

\section{Southern-blot hybridization of reverse transcriptase-mediated PCR (RT-PCR) products}

The first-strand cDNA was synthesized from total RNA $(1 \mu \mathrm{g})$ prepared from the pituitary or each different brain 
region with Moloney-murine-leukaemia virus reverse transcriptase (Promega) and an oligo(dT) primer in accordance with the manufacturer's instructions. The oligonucleotide primers used for the amplification of receptor cDNA fragments were $5^{\prime}$-CTCATTGTCATCATGTAT GCC-3' (identical to nucleotides 781-801) and 5'-TCA GCCATTCCACGCAGGGAT-3' (complementary to nucleotides 1267-1287). Primers for the amplification of $\beta$-actin cDNA fragments were 5'-GAGACCTTCAA CACCCCAG-3' (identical to nucleotides 310-328 in the quail $\beta$-actin gene; accession number AF199488) and 5'-GACAGAGTACTTGCGCTCAG-3' (complementary to nucleotides $935-954$ in the quail $\beta$-actin gene). PCR was performed with an initial denaturation step at $94{ }^{\circ} \mathrm{C}$ for $3 \mathrm{~min}$, followed by 35 cycles of $94^{\circ} \mathrm{C}$ for $1 \mathrm{~min}$, $54{ }^{\circ} \mathrm{C}$ for $1 \mathrm{~min}$ and $72{ }^{\circ} \mathrm{C}$ for $1 \mathrm{~min}$, and held at $72{ }^{\circ} \mathrm{C}$ for $3 \mathrm{~min}$. PCR products were resolved on a $1.5 \%(\mathrm{w} / \mathrm{v})$ agarose gel electrophoresis followed by transfer to a Hybond $\mathrm{N}^{+}$membrane (Amersham Biosciences). The membrane was hybridized with digoxigenin-labeled oligonucleotide probe (5'-AATGAGAACTTCCGACG GGGC-3'; identical to nucleotides 1093-1113). Digoxigenin labeling of DNA and detection were performed in accordance with the DIG system protocol (Roche Diagnostics).

\section{Results}

\section{Characterization of cDNA encoding GnIH receptor}

We first cloned a cDNA encoding a putative $\mathrm{GnIH}$ receptor in the quail diencephalon by a combination of $3^{\prime}$ and $5^{\prime}$ RACE, based on the receptor for rat RFRP, an orthologous peptide of GnIH. As shown in Fig. 1A, the nucleotide and deduced amino acid sequences of a putative quail GnIH receptor revealed a full length of $1479 \mathrm{bp}$ and an open reading frame of $1197 \mathrm{bp}$ encoding 399 amino acid residues with a calculated molecular mass of $45.7 \mathrm{kDa}$. Analysis of this protein for regional hydrophobicity revealed seven putative transmembrane domains (TMs; underlined in Fig. 1A and depicted as seven hydrophobic peaks in Fig. 1B), connected by three cytosolic and three extracellular loops, extracellular $\mathrm{N}$-terminal and cytosolic C-terminal domains that are characteristic of GPCRs (Ostrowski et al. 1992, Sun et al. 2001). The predicted initiator methionine codon agreed with Kozak's first-AUG rule (Kozak 1989). There were four potential Asn-linked glycosylation sites, three near the N-terminus $\left(\mathrm{Asn}^{15,20,30}\right.$ ) and one in the second extracellular loop connecting TMIV and TMV (Asn ${ }^{196}$; Fig. 1A). This putative quail $\mathrm{GnIH}$ receptor contained eight Cys residues, while the $\mathrm{C}$-terminal Cys residue $\left(\mathrm{Cys}^{356}\right)$ may be a site for palmitoylation (O'Dowd et al. 1989, Watson \& Arkinstall 1994). The C-terminal region of this putative quail GnIH receptor contained five serines and one threonine which may be substrates for protein kinases
(Watson \& Arkinstall 1994). The nucleotide sequence data reported will appear in the DDBJ, EMBL and GenBank Nucleotide Sequence Databases under accession number AB183891.

Comparison of the deduced amino acid sequence of the putative quail $\mathrm{GnIH}$ receptor revealed a higher homology to the receptors for rat and human RFRP than to those for rat and human neuropeptide FF (NPFF; Fig. 2 and Table 1). The full length of the putative quail $\mathrm{GnIH}$ receptor displayed $68 \%$ and $48-50 \%$ amino acid identities to mammalian RFRP receptors and mammalian NPFF receptors, respectively (Table 1 ). Comparing only the TM regions of the putative $\mathrm{GnIH}$ receptor gave $81-86 \%$ and $71-73 \%$ amino acid identities to mammalian RFRP receptors and mammalian NPFF receptors, respectively (Table 1).

\section{Binding properties of $\mathrm{GnIH}$ receptor}

To assess the binding activity of the putative quail $\mathrm{GnIH}$ receptor, binding experiments were performed using ${ }^{125} \mathrm{I}-$ YANLPLRF-amide as a radioligand. The specific binding of ${ }^{125}$ I-YANLPLRF-amide to crude membranes, which were harvested from COS-7 cells transfected with the putative quail $\mathrm{GnIH}$ receptor cDNA, increased linearly with the increase of crude membranes within a range less than $1000 \mu \mathrm{g}$ protein per reaction tube (data not shown). In contrast, there was no specific binding to crude membranes of COS-7 cells expressing only the pcDNA3 1 vector. When the crude membrane fractions $(800 \mu \mathrm{g}$ protein) of COS-7 cells transfected with the putative quail $\mathrm{GnIH}$ receptor cDNA were incubated with different concentrations of ${ }^{125}$ I-YANLPLRF-amide for $1 \mathrm{~h}$ at $20{ }^{\circ} \mathrm{C}$, the specific binding increased and tended to equilibrate with respect to the concentration of the radioligand (Fig. 3, inset). Scatchard plots of the specific binding, which were constructed from the data of the saturation-binding experiment (Fig. 3, inset), showed a straight line, suggesting the presence of a single class of high-affinity binding sites, with a significant slope $(P<0 \cdot 01$; Fig. 3$)$. The dissociation constant $\left(K_{\mathrm{d}}\right)$ and the maximal binding sites $\left(B_{\max }\right)$ were calculated from the fitted line of the plot. The $K_{\mathrm{d}}$ value was $0.752 \mathrm{nM}$ with a $95 \%$ confidence interval of $0.595-1.03 \mathrm{nM}$ and the $B_{\max }$ was $24.8 \mathrm{fmol} / \mathrm{mg}$ protein with a $95 \%$ confidence interval of $22 \cdot 3-29 \cdot 4 \mathrm{fmol} / \mathrm{mg}$ protein (Fig. 3).

To examine the ligand specificity of the binding to crude membranes of COS-7 cells expressing the putative quail $\mathrm{GnIH}$ receptor, competition-binding experiments were performed using GnIH, GnIH-RP-1, GnIH-RP-2 and $\mathrm{GnIH}-\mathrm{OH}$ (C-terminally non-amidated $\mathrm{GnIH}$ ) as competitors. ${ }^{125}$ I-YANLPLRF-amide $(1.25 \mathrm{nM})$ and crude membranes $(800 \mu \mathrm{g}$ protein) were incubated with various amounts of competitors for $1 \mathrm{~h}$ at $20^{\circ} \mathrm{C}$. The binding of ${ }^{125}$ I-YANLPLRF-amide was inhibited as a function of the concentration of each GnIH, GnIH-RP-1 
qGnIH receptor rRFRP receptor hRFRP receptor rNPFF receptor hNPFF receptor

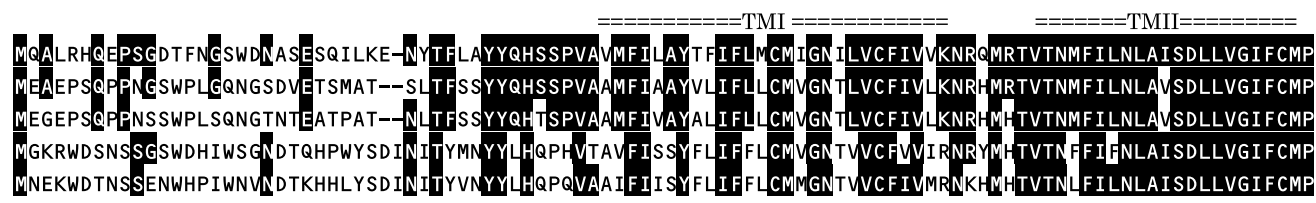

qGnIH receptor rRFRP receptor hRFRP receptor rNPFF receptor hNPFF receptor

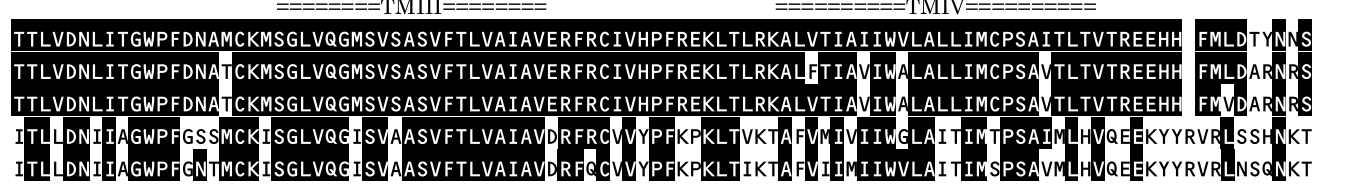

qGnIH receptor rRFRP receptor hRFRP receptor rNPFF receptor hNPFF receptor

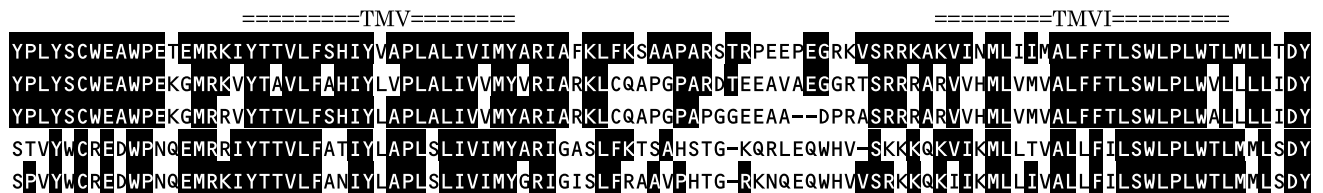

qGnIH receptor rRFRP receptor hRFRP receptor rNPFF receptor hNPFF receptor

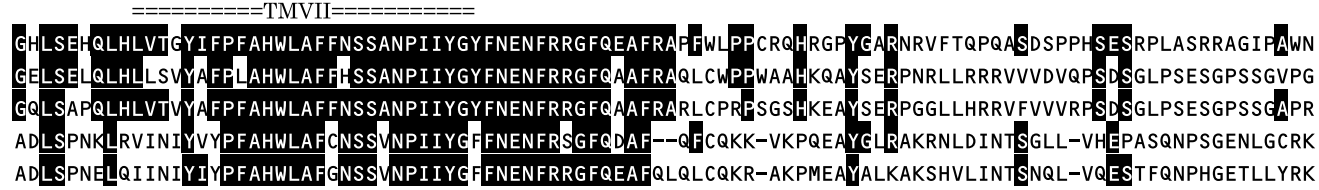

Figure 2 Amino acid sequence alignment of a putative quail GnlH $(q G n l H)$ receptor with the sequences of mammalian (rat, $r$, and human, h) RFRP and NPFF receptors. Amino acid residues that are identical to those in the putative quail GnlH receptor are shown in white against a black background. Putative TMs are indicated above the aligned sequences. Gaps introduced to obtain optimal alignment are indicated by dashes. Accession numbers: quail GnlH receptor, AB183891; rat RFRP receptor, AB040103; human RFRP receptor, AB040104; rat NPFF receptor, AF268900; human NPFF receptor, AF268899.

and GnIH-RP-2 (Fig. 4). In contrast, GnIH-OH failed to inhibit the binding even at high concentrations (Fig. 4). Competition-binding experiments were further performed using mammalian (RFRP) and amphibian (fGRP) orthologous peptides of $\mathrm{GnIH}$, a chicken fragment of GnIH (LPLRF-amide) and other neuropeptides (Metenkephalin-RF, galanin and neuropeptide Y) which lack the C-terminal LPXRF-amide motif. As shown in

Table 1 Amino acid identities of a putative quail GnlH receptor to mammalian RFRP and NPFF receptors

\begin{tabular}{|c|c|c|c|c|}
\hline & \multicolumn{4}{|c|}{ Amino acid identity (\%) } \\
\hline & rRFRP-r & hRFRP-r & rNPFF-r & hNPFF-r \\
\hline Full length & 68 & 68 & 48 & 50 \\
\hline Transmembrane & 81 & 86 & 71 & 73 \\
\hline
\end{tabular}

Abbreviations: rRFRP-r, rat RFRP receptor, (accession number AB040103); hRFRP-r, human RFRP receptor, (accession number AB040104); rNPFF-r, rat NPFF receptor, (accession number AF268900); hNPFF-r, human NPFF receptor, (accession number AF268899).
Table 2, orthologous peptides of GnIH (RFRP and fGRP) and chicken LPLRF-amide, a fragment of $\mathrm{GnIH}$, also inhibited the binding with similar $\mathrm{IC}_{50}$ values of $\mathrm{GnIH}$ and GnIH-RPs. However, neuropeptides lacking the C-terminal LPXRF-amide motif (Met-enkephalin-RF, galanin and neuropeptide $\mathrm{Y}$ ) did not inhibit the binding (Table 2).

Expression of $\mathrm{G} n I H$ receptor $m R N A$ in the pituitary and brain

The expression of mRNA encoding for the putative quail GnIH receptor was determined by Southern blotting analysis of RT-PCR products from the pituitary, different brain regions and spinal cord. As an internal control, we also detected the expression of mRNA encoding quail $\beta$-actin in each different tissue. The quail $\beta$-actin cDNA fragment with the size of about $645 \mathrm{bp}$ was amplified with the primer set based on the quail $\beta$-actin gene sequence in all tissues at a similar level (Fig. 5). In contrast, a single hybridized band for the $507 \mathrm{bp}$ RT-PCR product 


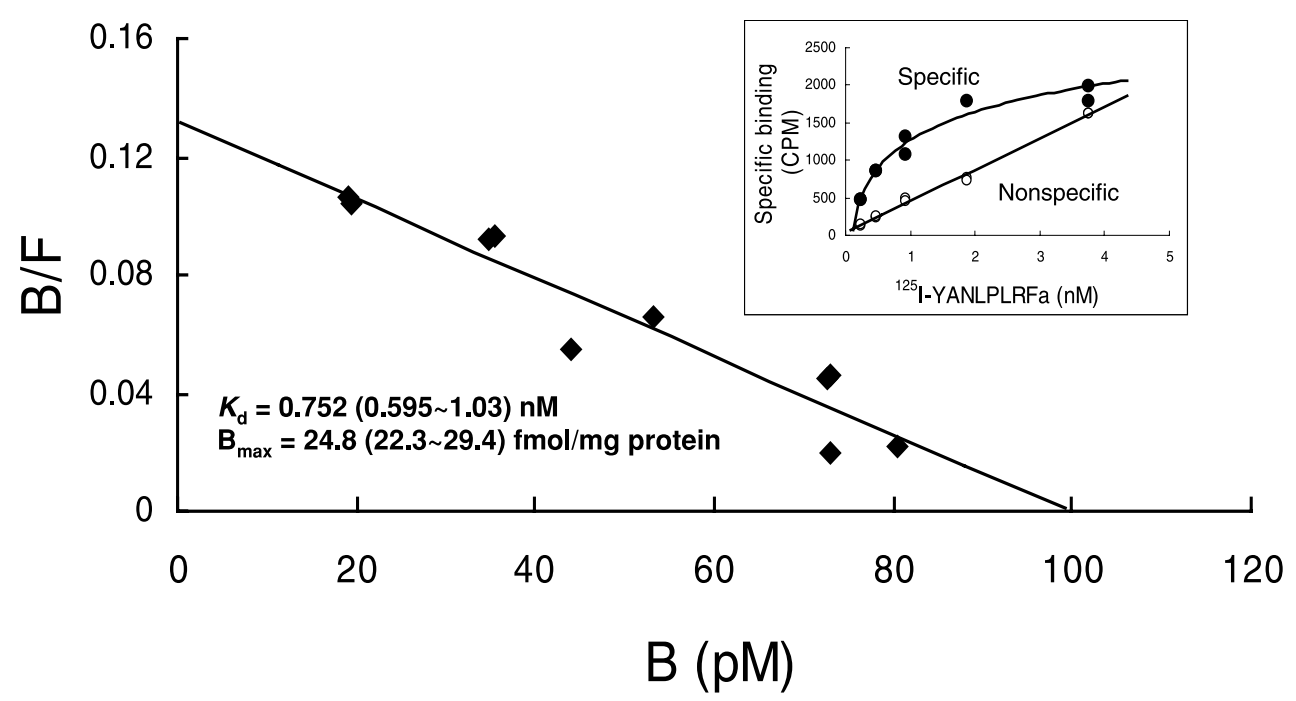

Figure 3 Scatchard plots of the binding of ${ }^{125}$ I-YANLPLRF-amide to the crude membrane fraction of COS-7 cells expressing a putative quail GnIH receptor. B, concentration of bound peptide at apparent equilibrium; F, concentration of free peptide at apparent equilibrium. Inset, saturation-binding data. $\bullet$ and $O$ represent specific and non-specific bindings of duplicate determinations, respectively.

between nucleotides 781 and 1287 was detected in the pituitary, cerebrum, diencephalon, mesencephalon and spinal cord, whereas no band was detected in the cerebellum (Fig. 5). The density of the band was relatively high in the diencephalon, mesencephalon and spinal cord (Fig. 5).

\section{Discussion}

We recently identified a novel hypothalamic neuropeptide inhibiting gonadotropin release in the quail and termed it

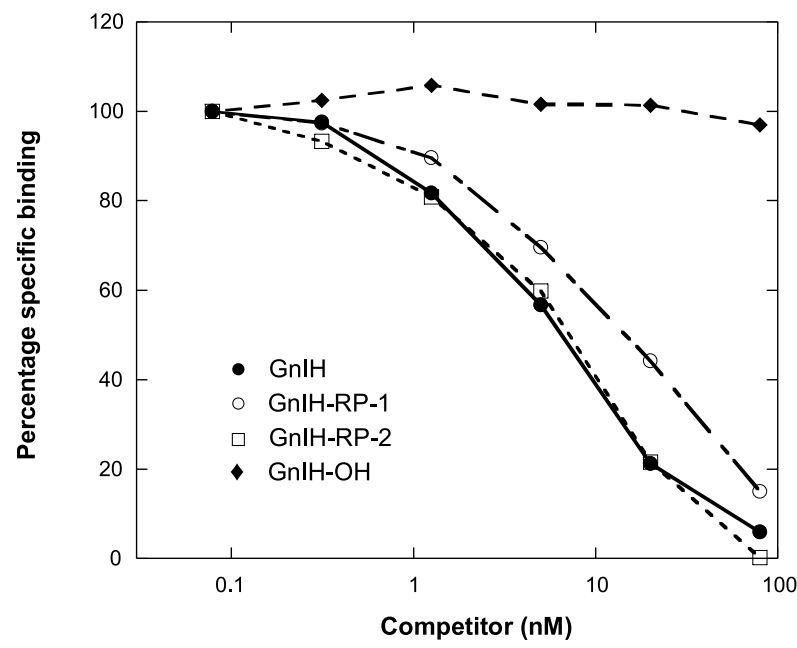

Figure 4 Competition of specific binding of ${ }^{125}$ I-YANLPLRF-amide to the crude membrane fraction of COS-7 cells expressing a putative quail GnlH receptor by unlabeled $\mathrm{GnlH}$, GnlH-RP-1, GnIH-RP-2 and GnIH-OH (C-terminally non-amidated $\mathrm{GnIH}$ ). Each point depicts the mean from duplicate determinations.
GnIH (Tsutsui et al. 2000). We will not fully understand the action of $\mathrm{GnIH}$ on gonadotropin release unless the receptor for $\mathrm{GnIH}$ is identified. In this study we therefore sought to identify the GnIH receptor in the quail. Based on the structure of the receptor for rat RFRP, a mammalian LPXRF-amide peptide (Hinuma et al. 2000) which is an orthologous peptide of quail GnIH (an avian LPXRF-amide peptide), we first cloned a cDNA encoding a putative GnIH receptor. This putative GnIH receptor is considered to possess seven TMs as a new member of the GPCR superfamily by the present structural and hydrophobic analyses. Furthermore, binding experiments using the crude membrane fraction of COS-7 cells transfected with the putative $\mathrm{GnIH}$ receptor cDNA indicated that this membrane protein specifically binds to GnIH and GnIH-RPs and possesses high-affinity binding sites for these peptides. Taken together, the identified $\mathrm{GnIH}$ receptor may be a functional receptor in the quail.

Although the receptors for rat and human RFRP (mammalian LPXRF-amide peptides) have been characterized by Hinuma et al. (2000), the presence of the receptors for non-mammalian LPXRF-amide peptides has been unclear. Thus the identified receptor for quail GnIH is a first demonstration of the presence of the nonmammalian LPXRF-amide peptide receptor. On the other hand, several groups have identified recently the receptors for rat and human NPFF, which are also GPCRs (Bonini et al. 2000, Elshourbagy et al. 2000, Kotani et al. 2001). Because the C-terminal sequence of NPFF, FLFQPQRF-NH $\mathrm{N}_{2}$, is closely related to those of RFRP and $\mathrm{GnIH}$, we compared the structure of the quail $\mathrm{GnIH}$ receptor with those of rat and human RFRP and NPFF. The deduced amino acid sequence of the quail GnIH 
Table 2 Ligand specificity of specific binding to a putative quail GnlH receptor

\begin{tabular}{|c|c|c|c|}
\hline & Animal & Sequence & $\mathbf{I C}_{50}(\mathrm{nM})$ \\
\hline \multicolumn{4}{|l|}{ Ligand } \\
\hline $\mathrm{GnIH}$ & Quail & SIKPSAYLPLRF-NH ${ }_{2}$ & $5 \cdot 79$ \\
\hline GnlH-RP-1 & Quail & SLNFEEMKDWGSKNFMKVNTPTVNKVPNSVANLPLRF-NH & $11 \cdot 65$ \\
\hline LPLRF-amide & Chicken & LPLRF-NH ${ }_{2}$ & $14 \cdot 06$ \\
\hline RFRP & Rat & ANMEAGTMSHFPSLPQRF-NH ${ }_{2}$ & $2 \cdot 75$ \\
\hline fGRP & Frog & SLKPAANLPLRF-NH ${ }_{2}$ & $3 \cdot 23$ \\
\hline Galanin & Quail & GWTLNSAGYLLGPHAVDNHRSFNDKHGFT-NH ${ }_{2}$ & $>1000$ \\
\hline Neuropeptide $Y$ & Human, rat & YPSKPDNPGEDAPAEDMARYYSALRHYINLITRQRY-NH ${ }_{2}$ & $>1000$ \\
\hline
\end{tabular}

receptor showed a higher homology to the receptors for rat and human RFRP (full length, 68\%; TMs, 81-86\%) than to those for rat and human NPFF (full length, 48-50\%;

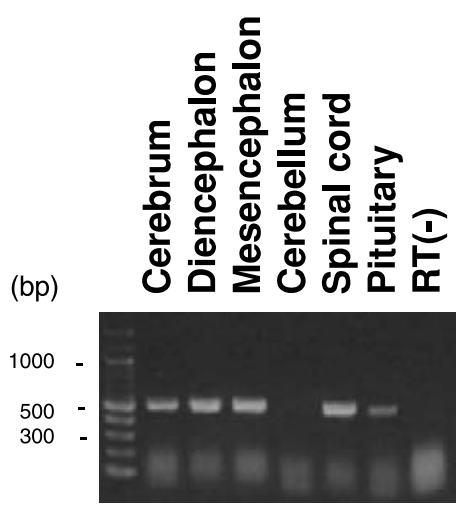

GnIH receptor (507 bp)

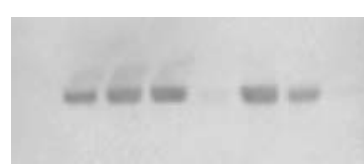

\section{Southern identification}

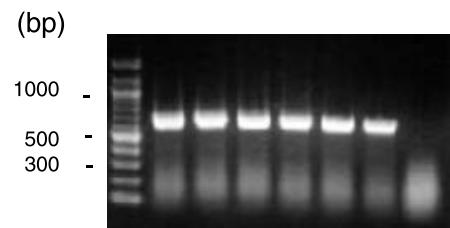

$\beta$-actin (645 bp)

Figure 5 RT-PCR analysis together with Southern hybridization of a putative quail GnlH receptor mRNA in the pituitary, different brain regions and spinal cord. The upper panel shows the gel electrophoresis of RT-PCR products for a putative quail $\mathrm{GnlH}$ receptor, the middle panel shows identification of the band by Southern hybridization using digoxigenin-labeled oligonucleotide probe for a putative quail $\mathrm{GnIH}$ receptor. cDNA corresponding to $1 \mu \mathrm{g}$ total RNA extracted from each tissue was used for a PCR reaction, and the PCR product was applied on one lane. The lane labeled RT (-) was left without the template as the negative control. The lower panel shows the RT-PCR for $\beta$-actin as the internal control. RT-PCR experiments were repeated five times using independently extracted RNA samples from different animals and produced similar results.
TMs, 71-73\%). The seven transmembrane-spanning domains are suggested to be oriented to form a ligandbinding pocket (Ostrowski et al. 1992, Watson \& Arkinstall 1994). The C-terminal LPXRF-amide motif of GnIH and RFRP may be a reason for a higher homology of the structure of TMs of these receptors. On the other hand, the presence of Cys residues in the first (Cys ${ }^{117}$ of quail $\mathrm{GnIH}$ receptor) and second (Cys ${ }^{204}$ of quail $\mathrm{GnIH}$ receptor) extracellular loops is a finding in many GPCRs. A disulfide linkage between these two Cys residues may play an important role in ligand interactions in the quail GnIH receptor, as suggested by O'Dowd et al. (1989), Ostrowski et al. (1992) and Watson \& Arkinstall (1994).

To demonstrate whether GnIH and GnIH-RPs can bind to the identified $\mathrm{GnIH}$ receptor, we subsequently conducted binding experiments in this study. The specific binding of the radioligand ${ }^{125}$ I-YANLPLRFamide (C-terminal of GnIH-RP-1 added tyrosine residue) to the crude membrane fraction of COS-7 cells transfected with the putative $\mathrm{GnIH}$ receptor cDNA was inhibited as a function of the concentration of GnIH, GnIH-RP-1 and GnIH-RP-2. In contrast, C-terminal non-amidated GnIH $(\mathrm{GnIH}-\mathrm{OH})$ failed to inhibit the specific binding, like other neuropeptides such as Met-enkephalin-RF, galanin and neuropeptide $\mathrm{Y}$, which lack the C-terminal LPXRF-amide motif. These results suggest that the identified GnIH receptor specifically binds to $\mathrm{GnIH}$ and GnIH-RPs in the quail. On the other hand, competitionbinding experiments indicated that RFRP and fGRP, mammalian and amphibian orthologs of GnIH, and chicken LPLRF-amide, a fragment of GnIH, also inhibited the specific binding. It is therefore considered that the identified $\mathrm{GnIH}$ receptor recognizes the C-terminal LPXRF-amide motif of these peptides as well as GnIH and GnIH-RPs. Scatchard plots showed the presence of high-affinity binding sites for GnIH and GnIH-RPs. The equilibrium $K_{\mathrm{d}}$ value calculated from the fitted line of the plots was $0.752 \mathrm{nM}$ (95\% confidence interval, 0.595$1.03 \mathrm{nM})$. Although physiological functions of GnIH-RPs are still uncertain in the quail, these data obtained by the 
present binding experiments suggest that not only $\mathrm{GnIH}$ but also GnIH-RPs exert their actions after binding to the identified GnIH receptor.

To elucidate the mode of action of GnIH on gonadotropin release, the expression of $\mathrm{GnIH}$ receptor mRNA was further characterized by Southern blotting analysis of the RT-PCR product. Interestingly, the GnIH receptor mRNA was expressed in the pituitary as well as several brain regions and spinal cord. The expression of $\mathrm{GnIH}$ receptor mRNA in the pituitary suggests that $\mathrm{GnIH}$ acts directly on the pituitary via GnIH receptor to inhibit gonadotropin release. This mode of action of GnIH is in agreement with our previous finding that cell bodies and terminals containing $\mathrm{GnIH}$ were localized in the paraventricular nucleus and median eminence, respectively (Tsutsui et al. 2000, Ubuka et al. 2003, Ukena et al. 2003a). In addition, we could detect a higher expression of $\mathrm{GnIH}$ receptor mRNA in the diencephalon including the hypothalamus. From our previous studies with quails (Ukena et al. 2003a) and sparrows (Bentley et al. 2003), GnIH-containing fibers were detected in extremely close proximity to GnRH neurons in the preoptic area. Bentley et al. (2004) and Osugi et al. (2004) further reported that in vivo treatment with $\mathrm{GnIH}$ rapidly inhibits GnRH-elicited luteinizing hormone release in sparrows. Therefore, it is plausible that $\mathrm{GnIH}$ could be acting at the level of the hypothalamus via GnIH receptor to inhibit gonadotropin release as well as at the pituitary. On the other hand, other brain regions, i.e. the cerebrum and mesencephalon, and the spinal cord also expressed $\mathrm{GnIH}$ receptor mRNA. This is consistent with our previous finding that GnIH-containing fibers were distributed throughout the diencephalic and mesencephalic regions as well as in the median eminence in birds (Bentley et al. 2003, Ukena et al. 2003a). The present and previous findings suggest multiple regulatory functions of $\mathrm{GnIH}$ in the avian brain. GnIH may participate not only in neuroendocrine functions but also in behavioral and autonomic mechanisms, because GnIH-containing fibers were found in the ventral paleostriatum, septal area, preoptic area, hypothalamus and optic tectum (Ukena et al. 2003a). Behavioral and physiological studies on the basis of these distributions of $\mathrm{GnIH}$ and $\mathrm{GnIH}$ receptor are now in progress.

\section{Funding}

This work was supported in part by Grants-in-Aid for Scientific Research from the Ministry of Education, Science and Culture, Japan (12440233, 12894021, 13210101, 15207007 and 16086206 (K T) and 15770040 $(\mathrm{K} \mathrm{U}))$. H Y is supported by a Research Fellowship from the Japan Society for the Promotion of Science (JSPS). There is no conflict of interest that would prejudice the impartiality of the research described in this article.

\section{References}

Azumaya Y \& Tsutsui K 1996 Localization of galanin and its binding sites in the quail brain. Brain Research 727 187-195.

Bentley GE, Perfito N, Ukena K, Tsutsui K \& Wingfield JC 2003 Gonadotropin-inhibitory peptide in song sparrows (Melospiza melodia) in different reproductive conditions, and in house sparrows (Passer domesticus) relative to chicken-gonadotropin-releasing hormone. Journal of Neuroendocrinology 15 794-802.

Bentley GE, Perfito N, Moore IT, Ukena K, Tsutsui K \& Wingfield JC 2004 Gonadotropin-inhibitory hormone in birds: possible modes of action. Acta Zoologica Sinica (In Press).

Bliss CI 1967 Statistics in Biology, vol 1, pp 253-257. New York: McGraw-Hill.

Bonini JA, Jones KA, Adham N, Forray C, Artymyshyn R, Durkin MM, Smith KE, Tamm JA, Boteju LW, Lakhlani PP et al. 2000 Identification and characterization of two $G$ protein-coupled receptors for neuropeptide FF. The Journal of Biological Chemistry 275 39324-39331.

Chartrel N, Dujardin C, Leprince J, Desrues L, Tonon MC, Cellier E, Cosette P, Jouenne T, Simonnet G \& Vaudry H 2002 Isolation, characterization, and distribution of a novel neuropeptide, Rana RFamide (R-RFa), in the brain of the European green frog Rana esculenta. The Journal of Comparative Neurology 448 111-127.

Dockray GJ, Reeve JR Jr, Shively J, Gayton RJ \& Barnard CS 1983 A novel active pentapeptide from chicken brain identified by antibodies to FMRFamide. Nature 305 328-330.

Elshourbagy NA, Ames RS, Fitzgerald LR, Foley JJ, Chambers JK, Szekeres PG, Evans NA, Schmidt DB, Buckley PT, Dytko GM et al. 2000 Receptor for the pain modulatory neuropeptides FF and $\mathrm{AF}$ is an orphan G protein-coupled receptor. Journal of Biological Chemistry 275 25965-25971.

Fukusumi S, Habata Y, Yoshida H, Iijima N, Kawamata Y, Hosoya M, Fujii R, Hinuma S, Kitada C, Shintani Y et al. 2001 Characteristics and distribution of endogenous RFamide-related peptide-1. Biochimica et Biophysica Acta 1540 221-232.

Hinuma S, Shintani Y, Fukusumi S, Iijima N, Matsumoto Y, Hosoya M, Fujii R, Watanabe T, Kikuchi K, Terao Y et al. 2000 New neuropeptides containing carboxy-terminal RFamide and their receptor in mammals. Nature Cell Biology 2 703-708.

Koda A, Ukena K, Teranishi H, Ohta S, Yamamoto K, Kikuyama S \& Tsutsui K 2002 A novel amphibian hypothalamic neuropeptide: isolation, localization, and biological activity. Endocrinology 143 411-419.

Kotani M, Mollereau C, Detheux M, Le Poul E, Brézillon S, Vakili J, Mazarguil H, Vassart G, Zajac JM \& Parmentier M 2001 Functional characterization of a human receptor for neuropeptide FF and related peptides. British Journal of Pharmacology 133 138-144.

Kozak M 1989 The scanning model for translation: an update. Journal of Cell Biology 108 229-241.

O'Dowd BF, Hnatowich M, Caron MG, Lefkowitz RJ \& Bouvier M 1989 Palmitoylation of the human $\beta_{2}$-adrenergic receptor. The Journal of Biological Chemistry 264 7564-7569.

Ostrowski J, Kjelsberg MA, Caron MG \& Lefkowitz RJ 1992 Mutagenesis of the $\beta_{2}$-adrenergic receptor: how structure elucidates function. Annual Review of Pharmacology and Toxicology 32 167-183.

Osugi T, Ukena K, Bentley GE, O’Brien S, Moore IT, Wingfield JC \& Tsutsui K 2004 Gonadotropin-inhibitory hormone in Gambel's white-crowned sparrow (Zonotrichia leucophrys gambelii): cDNA identification, transcript localization and functional effects in laboratory and field experiments. Journal of Endocrinology 182 $33-42$.

Samson WK, Keown C, Samson CK, Samson HW, Lane B, Baker JR \& Taylor MM 2003 Prolactin-releasing peptide and its homolog RFRP-1 act in hypothalamus but not in anterior pituitary gland to stimulate stress hormone secretion. Endocrine 20 59-66.

Satake H, Hisada M, Kawada T, Minakata H, Ukena K \& Tsutsui K 2001 Characterization of a cDNA encoding a novel avian 
hypothalamic neuropeptide exerting an inhibitory effect on gonadotropin release. Biochemical Journal 354 379-385.

Sawada K, Ukena K, Kikuyama S \& Tsutsui K 2002a Identification of a cDNA encoding a novel amphibian growth hormone-releasing peptide and localization of its transcript. Journal of Endocrinology 174 395-402.

Sawada K, Ukena K, Satake H, Iwakoshi E, Minakata H \& Tsutsui K $2002 b$ Novel fish hypothalamic neuropeptide: cloning of a cDNA encoding the precursor polypeptide and identification and localization of the mature peptide. European Journal of Biochemistry $2696000-6008$.

Sun YM, Flanagan CA, Illing N, Ott TR, Sellar R, Fromme BJ, Hapgood J, Sharp P, Sealfon SC \& Millar RP 2001 A chicken gonadotropin-releasing hormone receptor that confers agonist activity to mammalian antagonists. Journal of Biological Chemistry 276 7754-7761.

Tsutsui K \& Ishii S 1978 Effects of follicle-stimulating hormone and testosterone on receptors of follicle-stimulating hormone in the testis of the immature Japanese quail. General and Comparative Endocrinology 36 297-305.

Tsutsui K \& Ishii S 1980 Hormonal regulations of follicle-stimulating hormone receptors in the tests of Japanese quail. Journal of Endocrinology 85 511-518.

Tsutsui K, Shimizu A, Kawamoto K \& Kawashima S 1985 Developmental changes in the binding of follicle-stimulating hormone (FSH) to testicular preparations of mice and the effects of hypophysectomy and administration of FSH on the binding. Endocrinology 117 2534-2543.

Tsutsui K, Li D, Azumaya Y, Muneoka Y, Minakata H \& Nomoto K 1997 Demonstration, localization, and development of galanin receptors in the quail oviduct. Journal of Experimental Zoology 277 $57-65$.

Tsutsui K, Li D, Ukena K, Kikuchi M \& Ishii S 1998 Developmental changes in galanin receptors in the quail oviduct and the effect of ovarian sex steroids on galanin receptor induction. Endocrinology 139 4230-4236.
Tsutsui K, Saigoh E, Ukena K, Teranishi H, Fujisawa Y, Kikuchi M, Ishii S \& Sharp PJ 2000 A novel avian hypothalamic peptide inhibiting gonadotropin release. Biochemical and Biophysical Research Communications 275 661-667.

Ubuka T, Ueno M, Ukena K \& Tsutsui K 2003 Developmental changes in gonadotropin-inhibitory hormone in the Japanese quail (Coturnix japonica) hypothalamo-hypophysial system. Journal of Endocrinology 178 311-318.

Ukena K \& Tsutsui K 2004 A new member of the hypothalamic RF-amide peptide family, LPXRF-amide peptides: structure, localization and function. Mass Spectrometry Reviews (In Press).

Ukena K, Iwakoshi E, Minakata H \& Tsutsui K 2002 A novel rat hypothalamic RFamide-related peptide identified by immunoaffinity chromatography and mass spectrometry. FEBS Letters $\mathbf{5 1 2} 255-258$.

Ukena K, Ubuka T \& Tsutsui K 2003a Distribution of a novel avian gonadotropin-inhibitory hormone in the quail brain. Cell and Tissue Research 312 73-79.

Ukena K, Koda A, Yamamoto K, Kobayashi T, Iwakoshi-Ukena E, Minakata H, Kikuyama S \& Tsutsui K 2003b Novel neuropeptides related to frog growth hormone-releasing peptide: isolation, sequence, and functional analysis. Endocrinology 144 3879-3884.

Watson S \& Arkinstall S 1994 The G-protein Linked Receptor Facts Book, pp 2-6. London: Academic Press.

Yoshida H, Habata Y, Hosoya M, Kawamata Y, Kitada C \& Hinuma S 2003 Molecular properties of endogenous RFamide-related peptide-3 and its interaction with receptors. Biochimica et Biophysica Acta 1593 151-157.

Received 22 July 2004

Accepted 29 September 2004

Made available online as an

Accepted Preprint 5 October 2004 